\title{
The Effect of Chromium on the Roasting Process of Vanadium Extraction
}

\author{
Dong Liu, Xiangxin Xue and He Yang * \\ Institute of Metallurgical Resources and Environmental Engineering, Northeastern University, Shenyang 110819, \\ China; dongda1985@126.com (D.L.); xuexx@mail.neu.edu.cn (X.X.) \\ * Correspondence: yangh@smm.neu.edu.cn; Tel.: +86-139-098-13905
}

Academic Editor: Hugo F. Lopez

Received: 22 March 2016; Accepted: 21 June 2016; Published: 9 July 2016

\begin{abstract}
We simulated the roasting process of chromium by mixing $\mathrm{Cr}_{2} \mathrm{O}_{3}$ and $\mathrm{Na}_{2} \mathrm{CO}_{3}$ to analyze the influence of chromium on roasting vanadium slag. Samples were characterized by $\mathrm{XRD}$, thermal analysis and SEM at different temperatures: $\mathrm{Cr}_{2} \mathrm{O}_{3}$ and $\mathrm{Na}_{2} \mathrm{CO}_{3}$ began to react at $500{ }^{\circ} \mathrm{C}$. When the chromium oxide content was about $3.2 \%$, the conversion rate of $\mathrm{V}$ reached the maximum value of $95 \%$.
\end{abstract}

Keywords: vanadium slag; roasting; chromium

\section{Introduction}

Vanadium is an important metal used almost exclusively in ferrous and non-ferrous alloys due to its physicochemical and mechanical properties such as grain refinement, high tensile strength, hardness and fatigue resistance; it has a wide range of uses in the metallurgical and chemical sectors [1-3]. There are mainly three kinds of raw materials, bone coal, vanadium slag and waste vanadium catalyst, used to produce vanadium pentoxide in China. In addition, few foreign countries extract vanadium from petroleum residue, including the United States, Japan and others [4]. Vanadium slag is one of the most important sources of vanadium, which accounts for $58 \%$ of the production of vanadium [5].

The vanadium slag mixed with salt roasts in an oxidizing atmosphere, vanadium precipitates from the mineral structure and oxidizes to pentavalent vanadium oxide, and then vanadium pentoxide reacts with sodium oxide decomposed from sodium to form soluble sodium vanadate [6-8]. There is a lot of literature on the extraction of vanadium pentoxide from vanadium-containing material using $\mathrm{NaCl}, \mathrm{Na}_{2} \mathrm{SO}_{4}$, and $\mathrm{Na}_{2} \mathrm{CO}_{3}$ as additives [9-13]. The representative vanadium extraction route mainly consists of the following procedures: sodium salt roasting, water leaching, solution purification and $\mathrm{V}$ precipitation [5].

However, vanadium slag usually contains $3 \%-6 \%$ chromium (III) oxide in the form of chromium spinel, which is thermodynamically more stable than vanadium spinel and cannot be recovered at vanadium roasting temperatures [14].

Chromium is an important strategic resource, but hexavalent chromium is a highly toxic and carcinogenic substance, and it can corrode and damage the organism [14,15]. Hexavalent chromium is one of the key pollutants [14] that creates air, soil, surface and groundwater pollution [16], causes geological disasters, and is a long-term environmental pollution [17]. Chromium slag is one of the important sources of chromium pollution. Vanadium slag is a source of chromium slag, so it is a difficult problem to extract chromium from vanadium slag.

However, there are only a few studies of elements' effects on the salt roast vanadium process with the addition of calcium (every $1 \%$ increase of $\mathrm{CaO}$ in slag would cause a $4.7 \%-9.0 \% \mathrm{~V}_{2} \mathrm{O}_{5}$ loss [18]). This study will investigate the effect of chromium on salt roasting to provide a theoretical basis for the separation of chromium and vanadium in the future. The change in the mineralogy of vanadium slag 
was studied by XRD, SEM/EDS and TG-DSC techniques; the effect of the roasting temperature on vanadium extraction and the characterization of leach residues are also discussed.

\section{Experimental Materials and Experimental Procedure}

\subsection{Materials}

Vanadium slag before roasting was obtained from a steel production site in Chengde, China. Vanadium slag after roasting was obtained after extracting vanadium from vanadium slag.

Figure 1 shows that the main mineral phases in vanadium slag are mainly vanadium spinel $\mathrm{FeV}_{2} \mathrm{O}_{4}$, chromium spinel $\mathrm{FeCr}_{2} \mathrm{O}_{4}$, olivine $\mathrm{Fe}_{2} \mathrm{SiO}_{4}$, quartz $\mathrm{SiO}_{2}$ and so on. Figure 2 depicts the XRD pattern of vanadium slag after roasting; the main phases are iron oxide $\mathrm{Fe}_{2} \mathrm{O}_{3}$, magnetic iron oxide $\mathrm{Fe}_{3} \mathrm{O}_{4}$, quartz $\mathrm{SiO}_{2}$, diopside $(\mathrm{Ca}, \mathrm{Mn})(\mathrm{Mg}, \mathrm{Fe}, \mathrm{Mn}) \mathrm{Si}_{2} \mathrm{O}_{6}$, and sodium salt $\mathrm{NaCrSi}_{2} \mathrm{O}_{6}, \mathrm{NaFeO}_{2}$. The chemical compositions of vanadium slag before roasting and vanadium slag after roasting are given in Tables 1 and 2 .

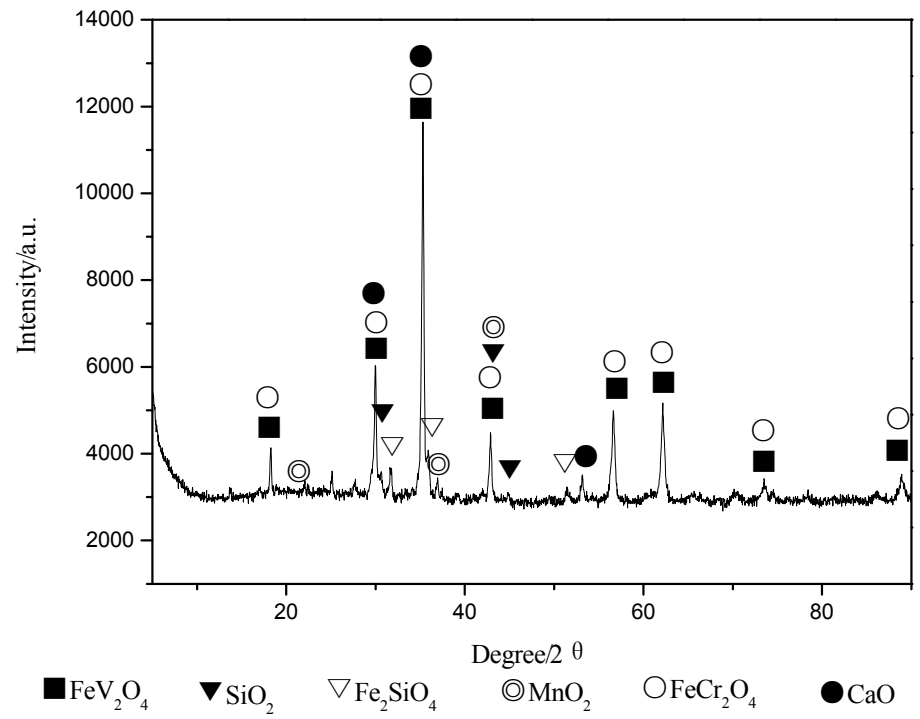

Figure 1. The XRD pattern of vanadium slag before roasting.

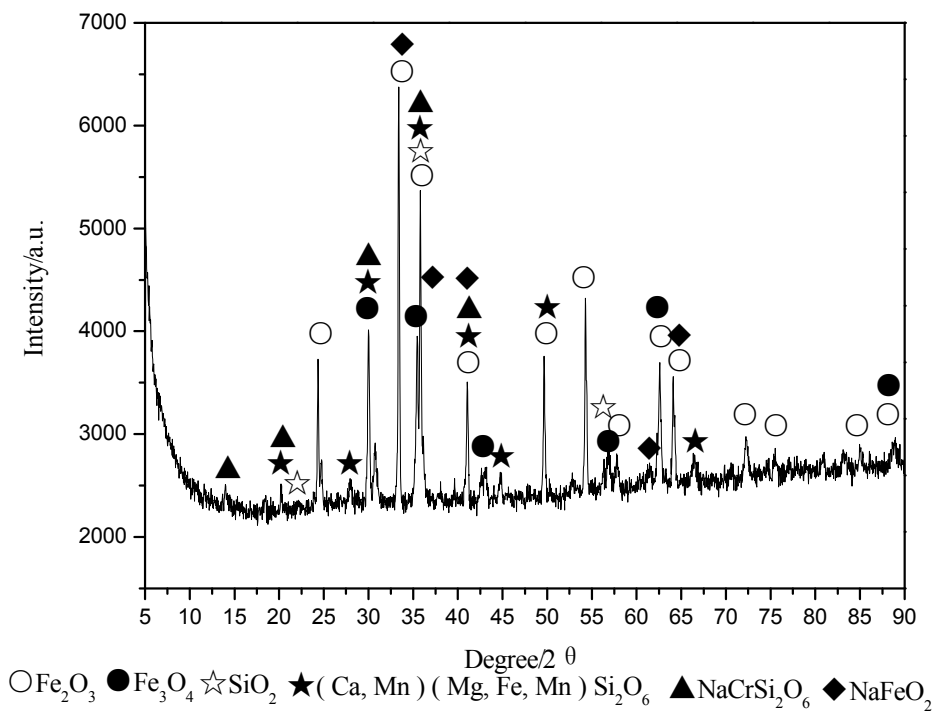

Figure 2. The XRD pattern of vanadium slag after roasting. 
Table 1. Chemical compositions of vanadium slag before roasting (wt. \%).

\begin{tabular}{cccccccccc}
\hline Component & $\mathrm{TFe}$ & $\mathbf{V}$ & $\mathrm{SiO}_{2}$ & $\mathrm{CaO}$ & $\mathrm{Mn}$ & $\mathrm{MgO}$ & $\mathrm{TiO}_{2}$ & $\mathrm{Cr}_{2} \mathrm{O}_{3}$ & $\mathbf{P}$ \\
\hline wt. $\%$ & 31.12 & 7.68 & 16.65 & 2.04 & 5.4 & 3.07 & 8.49 & 8.8 & 0.089 \\
\hline
\end{tabular}

Table 2. Chemical compositions of vanadium slag after roasting (wt. \%).

\begin{tabular}{cccccccccc}
\hline Component & $\mathrm{TFe}$ & $\mathbf{V}$ & $\mathrm{SiO}_{2}$ & $\mathrm{CaO}$ & $\mathrm{Mn}$ & $\mathrm{MgO}$ & $\mathrm{TiO}_{2}$ & $\mathrm{Cr}_{2} \mathrm{O}_{3}$ & $\mathbf{P}$ \\
\hline wt. $\%$ & 33.36 & 0.935 & 15.83 & 2.16 & 5.77 & 2.84 & 8.82 & 6.58 & 0.087 \\
\hline
\end{tabular}

We used sodium roasting technology to extract vanadium pentoxide from slag. It is the most mature technology, and domestic and foreign scholars have done a lot of related research [1,9,18-26].

Oxidative decomposition of spinel

$$
\begin{gathered}
\mathrm{FeO} \cdot \mathrm{V}_{2} \mathrm{O}_{3}+\mathrm{FeO}+1 / 2 \mathrm{O}_{2}=\mathrm{Fe}_{2} \mathrm{O}_{3} \cdot \mathrm{V}_{2} \mathrm{O}_{3} \\
\mathrm{Fe}_{2} \mathrm{O}_{3} \cdot \mathrm{V}_{2} \mathrm{O}_{3}+1 / 2 \mathrm{O}_{2}=\mathrm{Fe}_{2} \mathrm{O}_{3} \cdot \mathrm{V}_{2} \mathrm{O}_{4} \\
\mathrm{Fe}_{2} \mathrm{O}_{3} \cdot \mathrm{V}_{2} \mathrm{O}_{4}+1 / 2 \mathrm{O}_{2}=\mathrm{Fe}_{2} \mathrm{O}_{3} \cdot \mathrm{V}_{2} \mathrm{O}_{5} \\
\mathrm{Fe}_{2} \mathrm{O}_{3} \cdot \mathrm{V}_{2} \mathrm{O}_{5}=\mathrm{Fe}_{2} \mathrm{O}_{3}+\mathrm{V}_{2} \mathrm{O}_{5}
\end{gathered}
$$

Vanadium pentoxide reacts with the sodium salt to form water-soluble sodium vanadate

$$
\begin{gathered}
\mathrm{V}_{2} \mathrm{O}_{5}+\mathrm{Na}_{2} \mathrm{CO}_{3}=2 \mathrm{NaVO}_{3}+\mathrm{CO}_{2} \\
\mathrm{~V}_{2} \mathrm{O}_{5}+\mathrm{Na}_{2} \mathrm{SO}_{4}=2 \mathrm{NaVO}_{3}+\mathrm{SO}_{3} \\
\mathrm{~V}_{2} \mathrm{O}_{5}+2 \mathrm{NaCl}+\mathrm{H}_{2} \mathrm{O}=2 \mathrm{NaVO}_{3}+2 \mathrm{HCl} \text { (in Steam Atmosphere) } \\
\mathrm{V}_{2} \mathrm{O}_{5}+2 \mathrm{NaCl}+1 / 2 \mathrm{O}_{2}=2 \mathrm{NaVO}_{3}+\mathrm{Cl}_{2} \text { (in no Steam Atmosphere) }
\end{gathered}
$$

The reactions of chromium or vanadium in slag are:

$$
\begin{aligned}
\mathrm{Na}_{2} \mathrm{O}+\mathrm{Cr}_{2} \mathrm{O}_{3} & =\mathrm{Na}_{2} \mathrm{O} \cdot \mathrm{Cr}_{2} \mathrm{O}_{3} \\
\mathrm{Na}_{2} \mathrm{O}+\mathrm{V}_{2} \mathrm{O}_{5} & =\mathrm{Na}_{2} \mathrm{O} \cdot \mathrm{V}_{2} \mathrm{O}_{5} \\
2 \mathrm{Na}_{2} \mathrm{O}+\mathrm{V}_{2} \mathrm{O}_{5} & =2 \mathrm{Na}_{2} \mathrm{O} \cdot \mathrm{V}_{2} \mathrm{O}_{5} \\
3 \mathrm{Na}_{2} \mathrm{O}+\mathrm{V}_{2} \mathrm{O}_{5} & =3 \mathrm{Na}_{2} \mathrm{O} \cdot \mathrm{V}_{2} \mathrm{O}_{5}
\end{aligned}
$$

\subsection{Experimentation}

Sample pretreatment: With the raw materials in proportion (vanadium slag before roasting, vanadium slag after roasting, anhydrous sodium carbonate, sodium chloride), mixed ingredients into the blender for $3 \mathrm{~h}$, roasted into the vertical muffle furnace, stirred raw when roasting. A temperature controller was used to maintain the predetermined furnace temperature, with the furnace door kept open to maintain an oxidizing atmosphere. After roasting was completed, cooled the sample in water according to the ratio of liquid poured. The liquid was heated at $80^{\circ} \mathrm{C}$, and stirred $40 \mathrm{~min}$ at the rate of 200 revolutions / $\mathrm{min}$. Then the liquid was collected by filtration. The slurry was separated via vacuum filtration, and the residue was washed several times with distilled water. Ammonium ferrous sulfate titration was used to determine the concentration of vanadium in the solution.

Conversion of vanadium in sodium roasting stage was calculated with:

$$
\% \text { Conversion }=\frac{[V] \mathrm{s}}{[V]_{0}} \times 100 \%
$$


where $[\mathrm{V}]_{0}$ is the mass of $\mathrm{M}$ in the $\mathrm{V}-\mathrm{Cr}$ slag for the stage before roasting; $[\mathrm{V}] \mathrm{s}$ is the mass of vanadium after roasting. The conversions were calculated with concentration data in the leaching liquor instead of content data in the leaching residue due to the fact that it is difficult to determine the mass of all residues accurately and estimation of the mass will significantly increase the error. Parallel experiments were conducted three times and average extractions were obtained to ensure the validity of results.

\section{Effect of $\mathrm{Cr}_{2} \mathrm{O}_{3}$ on Vanadium Conversion Rate}

The controlled vanadium content in the mixture was $4.7 \%$ in this experiment, the alkali/vanadium ratio was 1.2 , and the alkali salt/vanadium ratio was $3.5 / 1$; it was insulated for $100 \mathrm{~min}$ at $780^{\circ} \mathrm{C}$ as shown in Table 3. Each set of experiments was repeated three times, average value was obtained to ensure the validity of results.

Table 3. Scheme of the influence of chrome oxide on the vanadium conversion experiment.

\begin{tabular}{cccccc}
\hline No. & $\mathbf{C r}_{\mathbf{2}} \mathbf{O}_{\mathbf{3}} \%$ & Temperature $/{ }^{\circ} \mathbf{C}$ & Time/min & Alkali Vanadium Ratio & Alkali Salt Ratio \\
\hline 1 & 8.39 & 780 & 100 & 1.2 & $3.5 / 1$ \\
2 & 7.00 & 780 & 100 & 1.2 & $3.5 / 1$ \\
3 & 5.25 & 780 & 100 & 1.2 & $3.5 / 1$ \\
4 & 4.42 & 780 & 100 & 1.2 & $3.5 / 1$ \\
5 & 4.00 & 780 & 100 & 1.2 & $3.5 / 1$ \\
6 & 3.80 & 780 & 100 & 1.2 & $3.5 / 1$ \\
7 & 3.23 & 780 & 100 & 1.2 & $3.5 / 1$ \\
8 & 2.54 & 780 & 100 & 1.2 & $3.5 / 1$ \\
\hline
\end{tabular}

As the Figure 3 shows, when the chromium oxide content was about $3.2 \%$, the conversion rate of $\mathrm{V}$ reached the maximum value of $95 \%$. When the chromium content was less than $3.2 \%, \mathrm{Cr}$ and spinel would react to form Cr-Mn spinel, which increased the conversion rate of vanadium, but when the chromium content was more than $3.2 \%$, the $\mathrm{Cr}-\mathrm{Mn}$ spinel content would not increase, and the excess chromium would compete with the vanadium to react with the sodium carbonate, resulting in a reduced vanadium conversion rate. When the chromium content was more than $5.24 \%$, the conversion rate of vanadium was gradually increased, and the reaction of $\mathrm{Cr}$ further decomposed the silicate and then increased the conversion rate of the vanadium. When the content of $\mathrm{Cr}_{2} \mathrm{O}_{3}$ in the mixture was between $3.229 \%-5.246 \%$, the conversion rate decreased $0.74 \%$ for each increase of $0.1 \% \mathrm{Cr}_{2} \mathrm{O}_{3}$. The maximum conversion rate is higher than that of $\mathrm{Li}$ [27] $\left(\mathrm{V}_{2} \mathrm{O}_{5}=7.8 \%, \mathrm{Cr}_{2} \mathrm{O}_{3}=2 \%\right)$ at $90 \%$ and $\mathrm{Li}[28]\left(\mathrm{V}_{2} \mathrm{O}_{5}=8.93 \%, \mathrm{Cr}_{2} \mathrm{O}_{3}=8.67 \%\right)$ at $88.6 \%$.

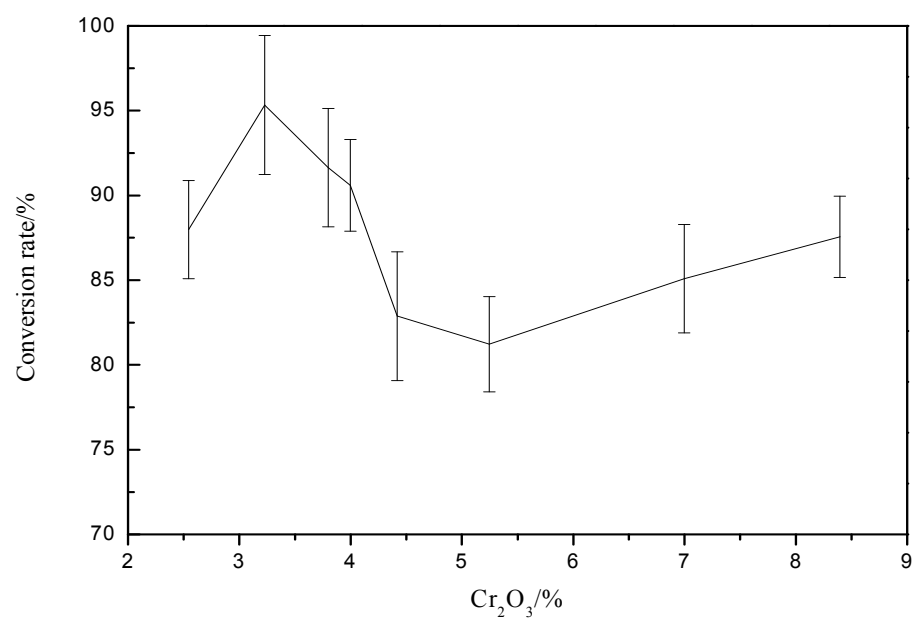

Figure 3. Effect of $\mathrm{Cr}_{2} \mathrm{O}_{3}$ content on vanadium conversion rate. 
Literature [29] indicates that the main components of the spinel central portion are $\mathrm{Cr}_{2} \mathrm{O}_{3}, \mathrm{~V}_{2} \mathrm{O}_{3}$, $\mathrm{MgO}$, and $\mathrm{FeO}$, of which $\mathrm{Cr}_{2} \mathrm{O}_{3}$ and $\mathrm{V}_{2} \mathrm{O}_{3}$ are the nucleation of monomer spinel. The chemical composition of the chromium-rich vanadium spinel central portion can be approximated considering $\left(\mathrm{Fe}^{2+} \mathrm{Mg}^{2+}\right)\left(\mathrm{Cr}^{3+} \mathrm{V}^{3+}\right) \mathrm{O}_{4}$. The optimum vanadium extraction temperature for transforming $\mathrm{Cr}_{2} \mathrm{O}_{3}$ to $\mathrm{CrO}_{4}{ }^{2-}$ was around $1200{ }^{\circ} \mathrm{C}$ by chromite $\mathrm{FeCr}_{2} \mathrm{O}_{4}$, and the first roasting conversion rate of $\mathrm{Cr}_{2} \mathrm{O}_{3}$ was usually less than $20 \%$ in slag at the optimum calcination temperature $\left(<850{ }^{\circ} \mathrm{C}\right)$. Thus, the chemical stability of the chromium-rich vanadium spinel is higher, which makes the crystal structure of the central portion of the vanadium-containing spinels remain more complete under calcination conditions, and a relatively complete crystal structure will restrict the soluble transforming of part of $\mathrm{V}_{2} \mathrm{O}_{3}$ in the crystal. With greater content of $\mathrm{Cr}_{2} \mathrm{O}_{3}$ and a larger size of the vanadium slag, this phenomenon is more obvious. Therefore, it is very unfavorable for the realization of disposable roasting vanadium when there is a great deal of $\mathrm{Cr}_{2} \mathrm{O}_{3}$ in the vanadium slag.

\section{The Mechanism of Chromium on in the Roasting of Vanadium Slag}

\subsection{XRD Analysis}

The XRD pattern (Figure 4) shows that in the initial low-temperature sintering conditions (300, $400{ }^{\circ} \mathrm{C}$ ), the sample phases are $\mathrm{Na}_{2} \mathrm{CO}_{3}$ and $\mathrm{Cr}_{2} \mathrm{O}_{3}$ and sodium chromate does not appear, which indicates that $\mathrm{Cr}_{2} \mathrm{O}_{3}$ and $\mathrm{Na}_{2} \mathrm{CO}_{3}$ do not react at a low temperature. When the temperature reaches $500{ }^{\circ} \mathrm{C}$, there is a small amount of the $\mathrm{Na}_{2} \mathrm{CrO}_{4}$ phase in addition to $\mathrm{Na}_{2} \mathrm{CO}_{3}$ and $\mathrm{Cr}_{2} \mathrm{O}_{3}$, indicating that the reaction of $\mathrm{Cr}_{2} \mathrm{O}_{3}$ and $\mathrm{Na}_{2} \mathrm{CO}_{3}$ starts at a low temperature of $400-500{ }^{\circ} \mathrm{C}$.
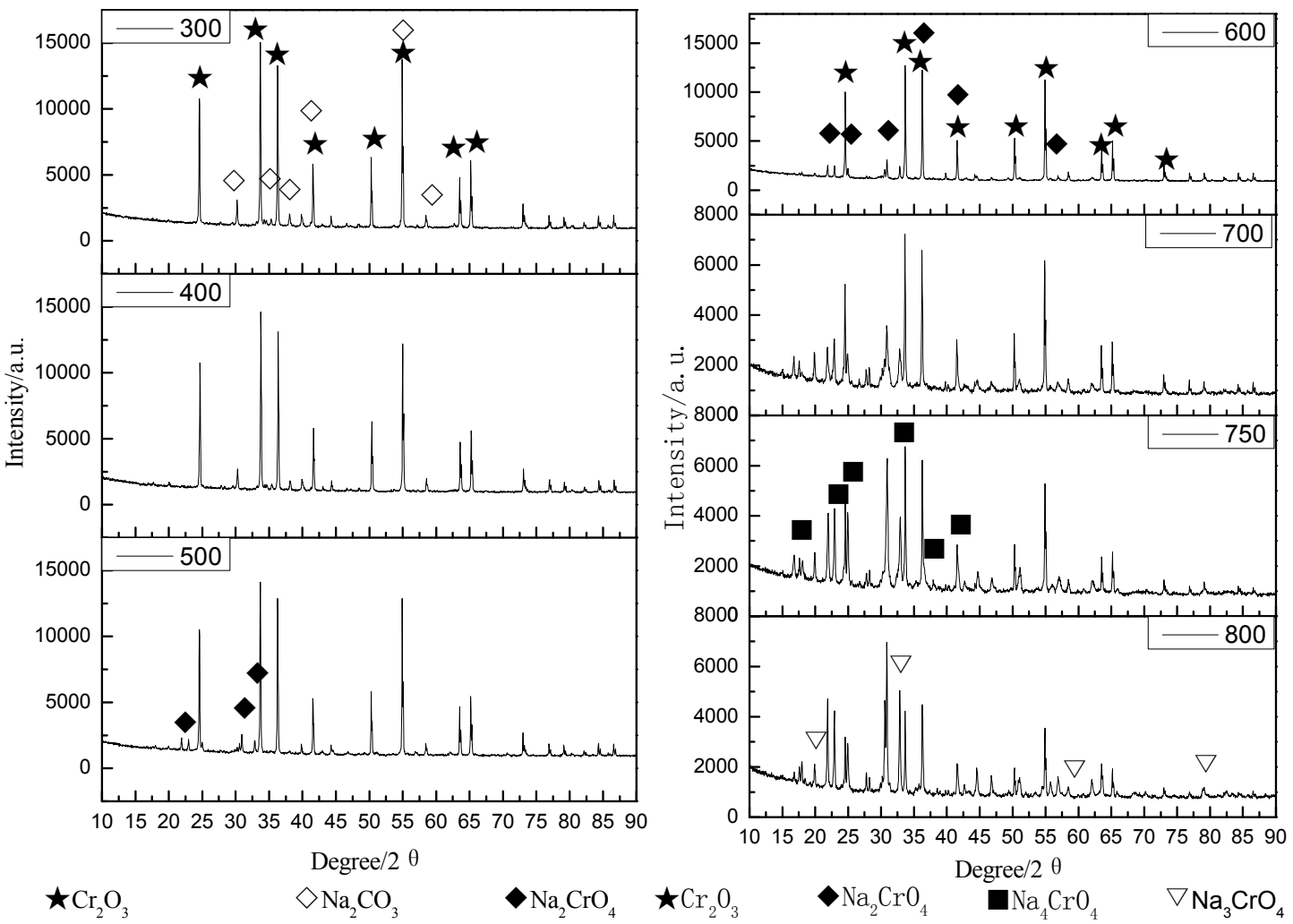

Figure 4. The XRD pattern of a sample of mixed $\mathrm{Na}_{2} \mathrm{CO}_{3}$ and $\mathrm{Cr}_{2} \mathrm{O}_{3}$ in a 1:1 ratio, at $300-800{ }^{\circ} \mathrm{C}$ for $1 \mathrm{~h}$.

At 600 and $700{ }^{\circ} \mathrm{C}$, the sample phase is still $\mathrm{Na}_{2} \mathrm{CO}_{3}, \mathrm{Cr}_{2} \mathrm{O}_{3}$ and $\mathrm{Na}_{2} \mathrm{CrO}_{4}$, but the peak intensity of $\mathrm{Na}_{2} \mathrm{CO}_{3}$ and $\mathrm{Cr}_{2} \mathrm{O}_{3}$ becomes weak, while the phase diffraction peak intensity of $\mathrm{Na}_{2} \mathrm{CrO}_{4}$ increases. In the sintering condition of $750{ }^{\circ} \mathrm{C}$, diffraction peaks of $\mathrm{Na}_{2} \mathrm{CO}_{3}$ disappear, the peak intensity of 
$\mathrm{Cr}_{2} \mathrm{O}_{3}$ continues to weaken, and the peak intensity of $\mathrm{Na}_{2} \mathrm{CrO}_{4}$ increases again while the new phase of $\mathrm{Na}_{4} \mathrm{CrO}_{4}$ appears. At $800{ }^{\circ} \mathrm{C}$, the peak intensity of $\mathrm{Cr}_{2} \mathrm{O}_{3}$ continues to decrease, while the peak intensity of $\mathrm{Na}_{2} \mathrm{CrO}_{4}$ enhances again and becomes the primary phase, and characteristic peaks of $\mathrm{Na}_{4} \mathrm{CrO}_{4}$ disappear and a new phase of $\mathrm{Na}_{3} \mathrm{CrO}_{4}$ is observed.

\subsection{Comprehensive Thermal Analysis}

Figure 5 is a TG-DTA curve of a sample of mixed $\mathrm{Cr}_{2} \mathrm{O}_{3}$ and $\mathrm{Na}_{2} \mathrm{CO}_{3}$ in a 1:1 ratio. Combined with $\mathrm{XRD}$, the figure shows the first weight loss is due to the removal of adsorbed water between room temperature to $200{ }^{\circ} \mathrm{C}$; the second weight loss is due to the decomposed $\mathrm{Na}_{2} \mathrm{CO}_{3}$ powders and liberated $\mathrm{CO}_{2}$ gas between $200-700{ }^{\circ} \mathrm{C}$; the endothermic peak around $100{ }^{\circ} \mathrm{C}$ is a removal reaction of the adsorbed water; and endothermic peak around $800^{\circ} \mathrm{C}$ is due to the reaction of $\mathrm{Na}_{4} \mathrm{CrO}_{4}$ by DTA (Differential Thermal Analysis).

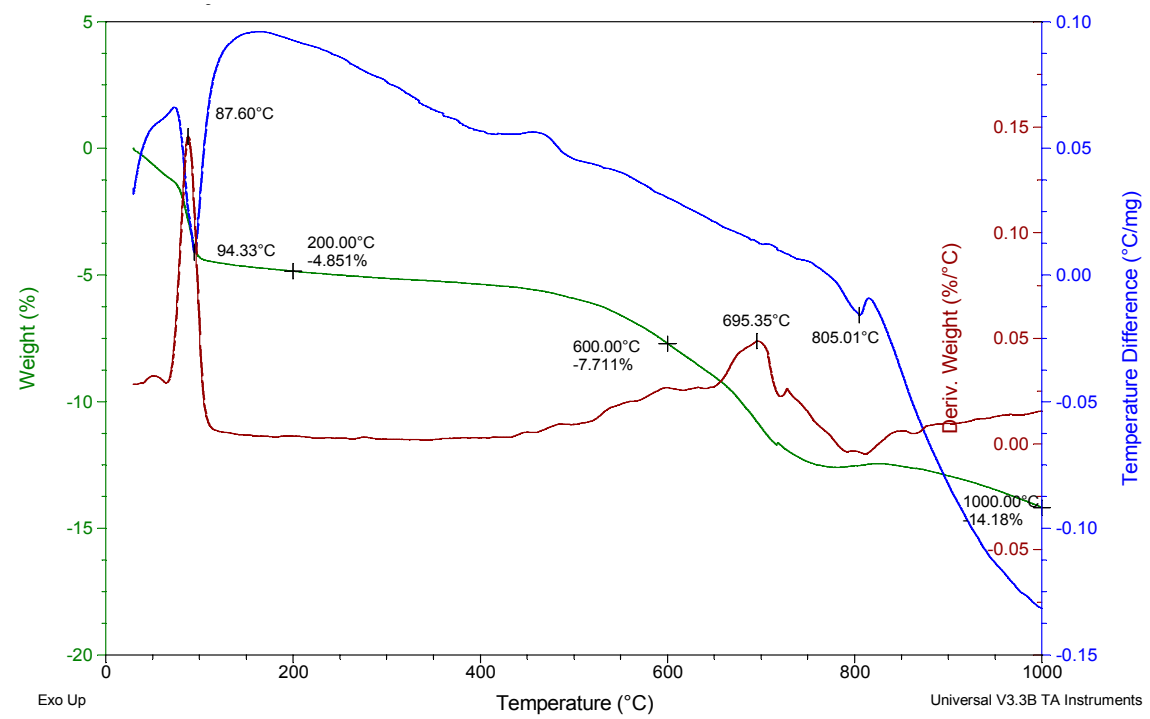

Figure 5. TG-DTA curve of sample mixed $\mathrm{Cr}_{2} \mathrm{O}_{3}$ and $\mathrm{Na}_{2} \mathrm{CO}_{3}$ in a 1:1 ratio.

\subsection{SEM Analysis}

Figure 6 shows the SEM image of a sample of mixed $\mathrm{Cr}_{2} \mathrm{O}_{3}$ and $\mathrm{Na}_{2} \mathrm{CO}_{3}$ in a 1:1 ratio, at different temperatures for one hour. The sample at $300{ }^{\circ} \mathrm{C}$ is composed of the irregular large blocky particles and uniform elliptical small particles, and the elliptical small particles enrich on the surface of the larger block particles. The two kinds of particles are substantially independent of each other. According to $\mathrm{XRD}$ analysis, there is no reaction substantially occurring in the sample at $300{ }^{\circ} \mathrm{C}$, so the product is still composed of $\mathrm{Cr}_{2} \mathrm{O}_{3}$ and $\mathrm{Na}_{2} \mathrm{CO}_{3}$. However, the sample begins to cohere together. The apparent morphology and characteristics of the sample at $400{ }^{\circ} \mathrm{C}$ are similar to the sample at $300{ }^{\circ} \mathrm{C}$, but the blocky particle size decreases, while the elliptical-shaped particles appear slightly larger, and small particles show further agglomeration. According to XRD analysis results, the sample has no substantial reaction at $400{ }^{\circ} \mathrm{C}$, and the product is still composed of $\mathrm{Cr}_{2} \mathrm{O}_{3}$ and $\mathrm{Na}_{2} \mathrm{CO}_{3}$ powder. The figure shows that, compared with the sample at 300 and $400{ }^{\circ} \mathrm{C}$, blocky large particles in the sample at $500{ }^{\circ} \mathrm{C}$ basically disappear. According to XRD analysis results, the sample begins to react at $500{ }^{\circ} \mathrm{C}$ and is composed of $\mathrm{Na}_{2} \mathrm{CO}_{3}, \mathrm{Cr}_{2} \mathrm{O}_{3}$ and $\mathrm{Na}_{2} \mathrm{CrO}_{4}$. The product at $600{ }^{\circ} \mathrm{C}$ is similar to the sample at $500{ }^{\circ} \mathrm{C}$ and mainly consists of a $1 \mu \mathrm{m}$ powder composition, approximately elliptical, but some particles start to fuse together. Combined with XRD analysis results, the sample at $600{ }^{\circ} \mathrm{C}$ is also composed of $\mathrm{Na}_{2} \mathrm{CO}_{3}, \mathrm{Cr}_{2} \mathrm{O}_{3}$ and $\mathrm{Na}_{2} \mathrm{CrO}_{4}$. At the temperature of $700{ }^{\circ} \mathrm{C}$, the sample consists of smaller particles, with obvious agglomeration, but the small particles melt together to form larger particles of different shapes and different sizes. Combined with XRD analysis results, the sample at $700{ }^{\circ} \mathrm{C}$ is also composed 
of $\mathrm{Na}_{2} \mathrm{CO}_{3}, \mathrm{Cr}_{2} \mathrm{O}_{3}$ and $\mathrm{Na}_{2} \mathrm{CrO}_{4}$, similar to the sample at 500 and $600{ }^{\circ} \mathrm{C}$. The sample at $750{ }^{\circ} \mathrm{C}$ consists of a small number of small particles of 1-2 $\mu \mathrm{m}$ and large particles of different shapes; all the different-sized particles get together, and compared with the sample at $700{ }^{\circ} \mathrm{C}$, more particles fuse together. Combined with XRD analysis results, the sample at $750{ }^{\circ} \mathrm{C}$ is composed of $\mathrm{Cr}_{2} \mathrm{O}_{3}, \mathrm{Na}_{2} \mathrm{CrO}_{4}$ and $\mathrm{Na}_{4} \mathrm{CrO}_{4}$. The sample at $800{ }^{\circ} \mathrm{C}$ basic melts completely, with only a small part of the small particles enriching on the surface of large particles or getting together; the sample mainly consists of melted large particles and adsorbed or aggregated small particles. Combined with XRD analysis results at $800{ }^{\circ} \mathrm{C}$, the sample is composed of $\mathrm{Cr}_{2} \mathrm{O}_{3}, \mathrm{Na}_{2} \mathrm{CrO}_{4}$ and $\mathrm{Na}_{3} \mathrm{CrO}_{4}$.

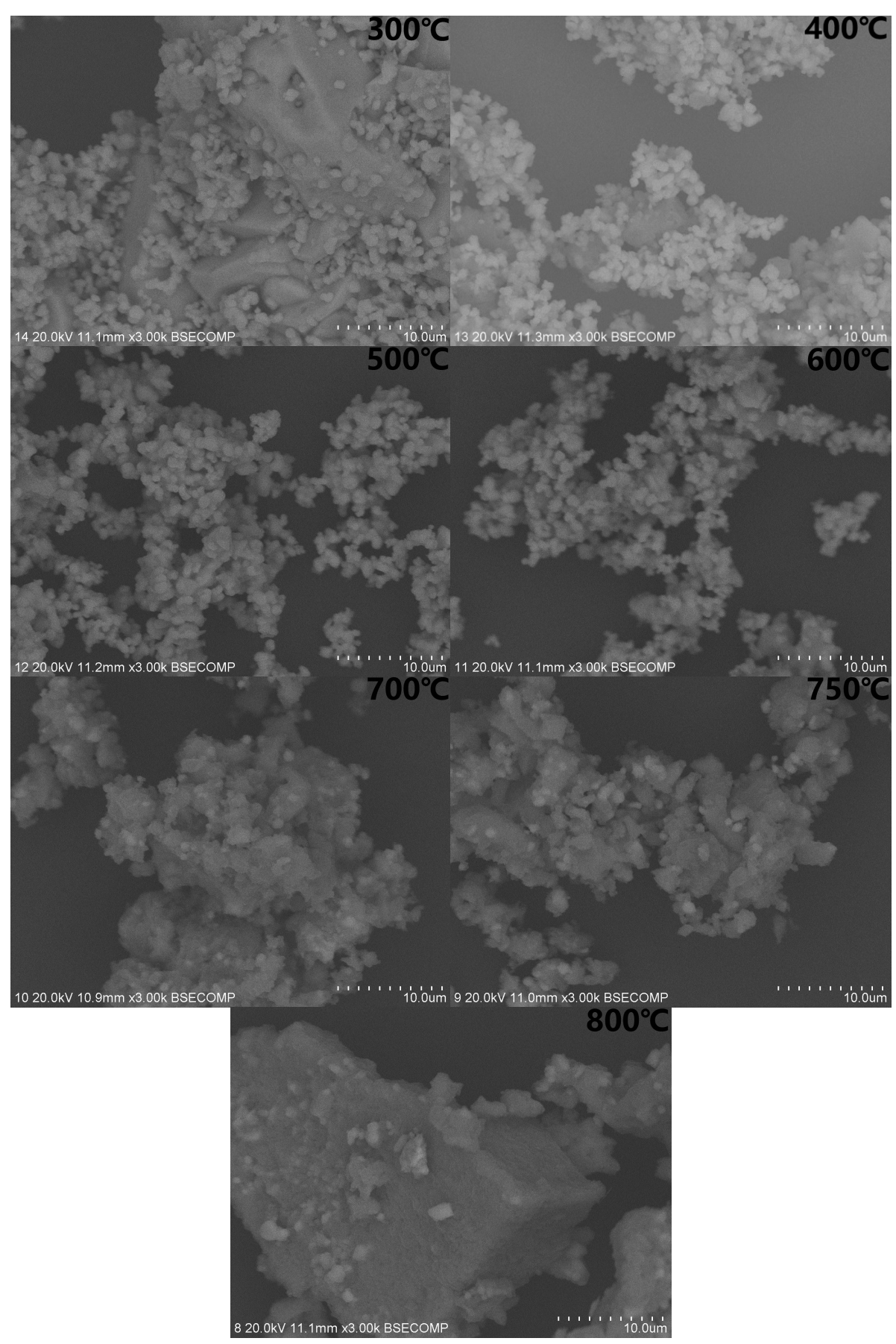

Figure 6. The SEM images of a sample of mixed $\mathrm{Cr}_{2} \mathrm{O}_{3}$ and $\mathrm{Na}_{2} \mathrm{CO}_{3}$ in a 1:1 ratio, at different temperatures for $1 \mathrm{~h}$. 


\section{Conclusions}

The mechanism of chromium on the roasting of vanadium slag has been given, and the effect of different contents of chromium on the conversion rate of vanadium in vanadium slag sodium-roasting has been studied.

1. $\mathrm{Cr}_{2} \mathrm{O}_{3}$ and $\mathrm{Na}_{2} \mathrm{CO}_{3}$ start the reaction at $500{ }^{\circ} \mathrm{C}$ and generate $\mathrm{Na}_{2} \mathrm{CrO}_{4}$, and the sample generates a new phase of $\mathrm{Na}_{4} \mathrm{CrO}_{4}$ at $750{ }^{\circ} \mathrm{C}$; when heating up to $800{ }^{\circ} \mathrm{C}, \mathrm{Na}_{4} \mathrm{CrO}_{4}$ decomposes to $\mathrm{Na}_{3} \mathrm{CrO}_{4}$. There are two weight loss intervals and one endothermic peak and one exothermic peak between room temperature to $1000^{\circ} \mathrm{C}$. Seen from the SEM, the particles begin to melt at $600{ }^{\circ} \mathrm{C}$.

2. When the chromium oxide content is about $3.2 \%$, the conversion rate of $\mathrm{V}$ reaches the maximum value of $95 \%$.

Acknowledgments: This work was supported by a grant from the National Natural Science Foundation (U1360204); National 973 Project (2013CB632603); National 863 project (2012AA062304) and Fundamental scientific research funds (N120602003).

Author Contributions: Dong Liu, Xiangxin Xue and He Yang conceived and designed the study. Dong Liu performed the experiments. Dong Liu wrote the paper. Dong Liu reviewed and edited the manuscript. All authors read and approved the manuscript.

Conflicts of Interest: The authors state that they have no conflict of interest.

\section{References}

1. Shi, L.; Wang, J.; Xie, J.H. Technology on Vanadium Extraction from Bone Coal by Adding Sodium Chloride. Min. Metall. Eng. 2008, 28, 58-61.

2. Cheng, L. Progress on Productive Technology of Vanadium Pentoxide. Gansu Metall. 2007, 29, 52-53.

3. Yu, Q.; Long, M.L. Treatment of Pollution in Production of Vanadium Pentoxide with Stone Coal Containing Vanadium. Environ. Eng. 2007, 25, 96-97.

4. Xi, X.; Yao, Q.; Hu, K.J. Present situation of production technology abroad about extraction of vanadium containing vanadium from oil slag. World Nonferrous Met. 2001, 5, 36-40.

5. Raja, B.V.R. Vanadium market in the world. Steelworld 2007, 13, 19-22.

6. Lin, H.L. Study on vanadium extraction from Fangshankou bone coal in GansuDunhuang; Chengdu University of Technology: Chengdu, China, 2000.

7. Zhang, Y.; Fan, B.W.; Peng, D.P. Research of Precipitation Poly-ammonium Vandate from Extraction Solution of Acid-leaching Bone Coal. Chin. J. Rare Met. 2001, 25, 157-160.

8. Chmielewski, A.G.; Urbaski, T.S.; Migda, W. Separation technologies for metals recovery from industrial wastes. Hydrometallurgy 1997, 45, 333-344. [CrossRef]

9. Gabra, G.; Malinsky, I. A comparative study of the extraction of vanadium from titaniferous magnetite and slag. In Proceedings of the 110th AIME Meeting, Metallurgical Society of AIME, Chicago, IL, USA, 22-26 February 1981; pp. 167-189.

10. Goddard, J.B.; Fox, J.S. Salt roasting of vanadium ores. In Proceedings of the 110th AIME Meeting, Chicago, IL, USA, 22-26 February 1981; pp. 127-145.

11. Lu, M.; Zhang, Y.M.; Liu, T.; Yang, D. Sintering Action of $\mathrm{NaCl}$ Calcination during Extracting Vanadium from Stone Coal. Chin. J. Rare Met. 2009, 33, 894-897.

12. Wang, M.Y.; Wang, X.W. Research Status and Prospect of Vanadium Leaching Processes from Stone Coal. Chin. J. Rare Met. 2010, 34, 90-97.

13. Shlewit, H.; Alibrahim, M. Extraction of Sulfur and Vanadium from Petroleum Coke by Means of Salt-roasting Treatment. Fuel 2006, 85, 878-880. [CrossRef]

14. Ji, Z. A summary of the harmfulness of chrome residue and its treatment. Inorg. Chem. Ind. 2003, 35, 1-4.

15. Ji, Z. The two key factors for disposal of chrome residue. Inorg. Chem. Ind. 2004, 36, 1-4.

16. Jagupilla, S.C.; Moon, D.H.; Waznea, M.; Christodoulatos, C.; Kim, M.G. Effects of particle size and acid addition on the remediation of chromite ore processing residue using ferrous sulfate. J. Hazard. Mater. 2009, 168, 121-128. [CrossRef] [PubMed] 
17. Geelhoed, J.S.; Meeussen, J.C.; Hillier, S.; Lumsdon, D.G.; Thomas, R.P.; Farmer, J.G.; Paterson, E. Identification and geochemical modeling of processes controlling leaching of $\mathrm{Cr}(\mathrm{VI})$ and other major elements from chromite ore processing residue. Geochim. Cosmochim. Acta 2002, 66, 3927-3942. [CrossRef]

18. Peng, Y.; Xie, T.L.; Zhou, Z.Q.; Pan, P.; Sun, X.H. Preparation $\mathrm{V}_{2} \mathrm{O}_{5}$ from Low Grade Vanadium bearing Slag of High Calcium and High Phosphor. Ferro-Alloys 2007, 38, 18-23.

19. Huang, D.X. Vanadium Extraction and Steelmaking; Metallurgical Industry Press: Beijing, China, 2000.

20. Wang, J.C.; Chen, H.S.; Li, G.S.; Xie, Q.L.; Deng, X.B. Production process from vanadium slag smelted in Pyongyang converter. Iron. Steel Vanadium Titanium 1998, 19, 41-46.

21. Wu, B. Extracting vanadium pentoxide from high silicon low-vanadium vanadium slag. Ferro-Alloys 2008, 200, 5-8.

22. Qiu, S.X.; Liu, X.S.; Zhou, D.; Gao, H.M.; Wang, P.P.; Jia, D.N.; Hu, F. Study on extracting vanadium pentoxide in vanadium slag. Inorg. Chem. Ind. 2010, 42, 46-48.

23. Li, H.; Zhou, R.Z.; Wang, W.J.; Li, J.J.; Wang, X. Method for Extracting $\mathrm{V}_{2} \mathrm{O}_{5}$ from Vanadium Slag. CN92108960.0, 23 February 1994.

24. Kozlov, V.A.; Demidov, A.E. Chemical principles of a technology for making pure vanadium pentoxide. Metallurgist 2000, 44, 428-433. [CrossRef]

25. Wen, S.D.; Ding, Y.X. Exploration of the factors of roasting conversion ratio for vanadium slag. J. Chengde Petrol. Coll. 1999, 1, 9-12.

26. Fu, Z.B.; Deng, J.B.; Zhang, L.; Gao, G.J.; Chen, H.J.; Gu, J.Y. Method for Extracting Vanadium from Sodium Roasting Clinker. ZL 200910176895.3, 23 September 2009.

27. Li, X.-S.; Xie, B.; Wang, G.-E.; Li, X.-J. Oxidation process of low-grade vanadium slag in presence of $\mathrm{Na}_{2} \mathrm{CO}_{3}$. Trans. Nonferrous Met. Soc. China 2011, 21, 1860-1867. [CrossRef]

28. Li, H.-Y.; Fang, H.-X.; Wang, K.; Zhou, W.; Yang, Z.; Yan, X.-M.; Ge, W.-S.; Li, Q.-W.; Xie, B. Asynchronous extraction of vanadium and chromium from vanadium slag by stepwise sodium roasting-water leaching. Hydrometallurgy 2015, 156, 124-135. [CrossRef]

29. Chen, D.H. Study on vanadium extraction from vanadium extraction residue. Inorg. Chem. Ind. 1993, 4, 28-32.

(C) 2016 by the authors; licensee MDPI, Basel, Switzerland. This article is an open access article distributed under the terms and conditions of the Creative Commons Attribution (CC-BY) license (http://creativecommons.org/licenses/by/4.0/). 